\title{
Sharing Place, Learning Together: the birthplace of new ways?
}

\section{Diversifying educational opportunities for remote Indigenous students is a key step to improving health outcomes}

Young people and old people, Bininj, Yol and Balanda; we need to stand together for the future. The health and wellbeing of our people and our country depends upon us all. ${ }^{1}$

Djelk Rangers Victor Rostron, Wesley Campion and Ivan Namarnyilk. (Djelk Indigenous Protected Area, Arnhem Land.) The terms Bininj and Yol are used in Maningrida to refer to Aboriginal people. Balanda is used colloquially throughout the Maningrida region to describe non-Aboriginal people.

In the north, water chestnuts bring people and magpie geese together. Magpie geese migrate to the flood plains from elsewhere in Australasia as the chestnuts ripen after the wet season, and humans and magpie geese share the chestnuts. People can hunt for magpie geese only after the geese have eaten the chestnuts and fattened, slowing their flight. Hunting and preparing the goose is a particular process that must be taught, and learnt, in the right way. Magpie geese and water chestnuts each have songlines, dreamings and a moiety, and you have to follow the rules exactly, the old people's way. Students at Maningrida College in Arnhem Land perform these life skills with their Indigenous teacher, Heleana Wauchope-Gulwa, around a traditional stringybark fire as part of the interagency governmentfunded Learning on Country (LoC) program. In the program, piloted at four remote Northern Territory schools, students are linked with their local Indigenous ranger group (in Maningrida, the Djelk Rangers) with whom part of their school program is spent "on country" (Box 1). As the students reflect later, magpie goose is "good for us, and good for our families".

International research reinforces that health outcomes for Indigenous populations are linked to a spectrum of social determinants that include education and access to culture. ${ }^{3,4}$ In this context, the LoC approach recognises that population health in remote Indigenous communities links to the health of "country": the land to which a community belongs and is culturally and physically connected. This in turn relies on Indigenous culture remaining strong, since the health of people, country and culture go hand-in-hand. ${ }^{1,5}$ It is not just the nutritional properties of the magpie geese, but the way education can bring together two learning systems and link to the physical, social, emotional and spiritual health and wellbeing of the community that make it "good" for Maningrida students.

The Australian Venom Research Unit (AVRU), part of the Department of Pharmacology at the University of Melbourne, was invited to contribute to Maningrida College's LoC program in 2010. The LoC students had
1 Students, teachers and members of the Sharing Place, Learning Together team search for water chestnuts east of Maningrida

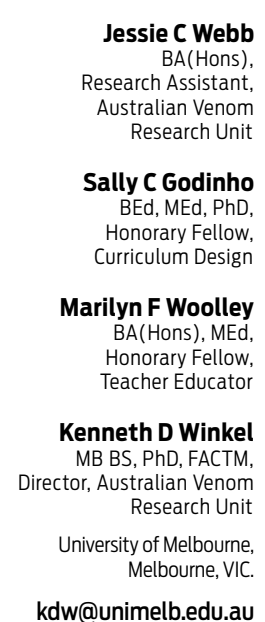

doi: 10.5694/mjal3.10565

Linking literacy, health and science to community life and culture can strengthen the curriculum

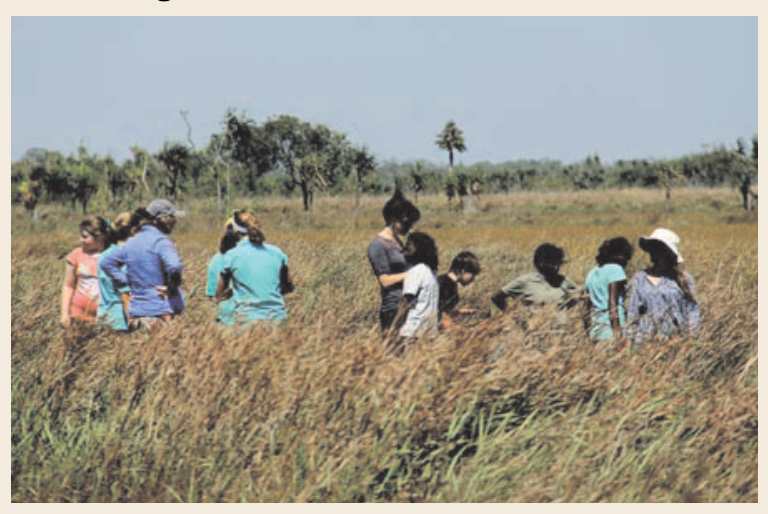

discovered 45 new species of spiders during local fieldwork activities, and science teacher Mason Scholes was seeking to expand the program's potential in respect to venom, venomous injury and biodiversity.

Coincidentally, the AVRU had just completed a project with the Melbourne Graduate School of Education, developing science-based curriculum resources combining injury prevention with science and health literacy, and had received an anonymous donation toward Indigenous-related research and education. In consultation with the Murrup Barak, Melbourne Institute for Indigenous Development and Indigenous leaders at the University of Melbourne, and guided by research linking health and education with a spectrum of social determinants, the Sharing Place, Learning Together (SPLT) project evolved (Box 2). ${ }^{4}$

Since 2010, the SPLT project, led by an interdisciplinary team with backgrounds in curriculum, pedagogy, literacy, science and health, has connected with Maningrida College's LoC program. Under the guidance of rangers and elders, the SPLT team has diversified the existing fieldwork program, partnering with outside institutions to link local biodiversity issues to a range of science and educational practices. The team has, additionally, worked to extend and strengthen the literacy focus of the LoC program, supporting the government's priority to increase literacy and numeracy development in remote schools. ${ }^{6,7}$ Here, students, rangers and traditional owners are active participants in the development of their own curriculum resources. Explicit scaffolding and teaching of literacy skills has empowered students to draw on their knowledge of country and write the text for a series of pocket books produced in 2011: Bush tucker, First aid, Catch ' $n$ ' cook and Animal tracks. These books were based on students' fieldwork experiences and familiarisation with tropical and remote first aid and injury prevention (Box 3). It was this experience of authorship that enabled the students 


\section{The Sharing Place, Learning Together (SPLT) program Background \\ This program focuses on the research and development of innovative approaches to education and capacity building in remote Aboriginal communities. SPLT aims to increase educational opportunities for rural and remote students as a key step to improving health, access to higher education and employment outcomes, by supporting: \\ - literacy, numeracy and science knowledge appropriate to remote community life \\ - education curriculum development and research \\ - Aboriginal health and resilience through capacity building \\ - a program that is grounded to place \\ Key partners \\ - Maningrida College (Maningrida, Northern Territory) \\ - Djelk Rangers (Bawinanga Aboriginal Corporation, Maningrida, NT) \\ - Australian Venom Research Unit (Department of Pharmacology) and the Melbourne Graduate School of Education, University of Melbourne (Victoria) \\ Specific activities \\ - curriculum development: the concepts underpinning curriculum development within the program integrate Aboriginal biocultural knowledge with Western scientific knowledge, and foster shared learnings, methods and skills \\ - field trips: students work with rangers and elders to map, interpret and share local biodiversity and cultural practices and to link these with school learning processes and outcomes \\ - book development: these projects aim to develop leadership, literacy and presentation skills. Students create context to communicate significant biocultural knowledge within the integrated classroom program \\ - Venom trail: this is a fieldwork program that connects rangers, scientists and students in local and wider contexts. It highlights the value of cross-cultural collaboration, higher education and capacity building}

to reflect, and document their knowledge, that hunting and cooking magpie geese was good for both them and their families.

The SPLT team is informed by the Australian National University's Centre for Aboriginal Economic Policy Research, which supports the development of experiential learning in community-based contexts. ${ }^{5}$ Further, the Centre's action research project People on country: vital landscapes, Indigenous futures has, over the past 5 years, explored the "links between Indigenous wellbeing, natural resource management and new resource-based development opportunities" in several Indigenous communities, including Maningrida. ${ }^{1}$ Its research shows that Indigenous-managed estates remain the most ecologically intact, but that Western science makes important contributions to present land management challenges.

Current policy focuses on "closing the gap" between Indigenous and non-Indigenous health, education and employment outcomes. ${ }^{7}$ However, there is concern that targets focused on closing statistical inequalities (from data on social and economic indicators) can risk directing remedies towards outcomes that, paradoxically, may widen the gap they seek to close. ${ }^{5,8}$ Data-based educational targets can prompt "teaching to the test" in disadvantaged schools where funding is linked to results of the National Assessment Program - Literacy and Numeracy (NAPLAN), leaving Indigenous students with a fragmented formal education. ${ }^{5}$ In addition, prioritising Western knowledge and world views in the classroom risks presenting a deficit-filled monocultural model of Indigenous Australia and subjugating the complexity and validity of Indigenous knowledge systems and cultures. $^{9}$

If narrower, prescriptive pedagogies replace contextbased educational approaches in remote settings, the impact is felt in communities like Maningrida where leaders worry that local knowledge and culture is not being transmitted to young people (Box 4). Linking literacy, health and science to community life and culture can strengthen the curriculum "both ways", because "lots of kids won't go to school, but ... out bush they attend and listen." 1 The LoC approach involves community participation in the school's programs, thereby encouraging school attendance and student engagement with learning. Community involvement and partnerships that are accountable "both ways" are recognised as being essential for successful educational outcomes. $^{10}$

Health, wellbeing, resilience and cultural livelihoods for remote communities are contingent on effective land management, the synthesis of Western science and traditional knowledge, the maintenance of biodiversity, and the opportunity for Indigenous people to remain active users, custodians and inhabitants of their lands. Environmental threats are serious for remote communities. Maningrida's surrounds contain sites of the very few still existing in Australia - where traditional land management practices remain unbroken, and biodiversity flourishes. ${ }^{11}$ Still, feral animals, weeds, illegal fishing and mining exploration threaten to disrupt traditional management practices

3 Pages from the First aid pocketbook created by Maningrida College students, describing first aid treatment for box jellyfish stings*

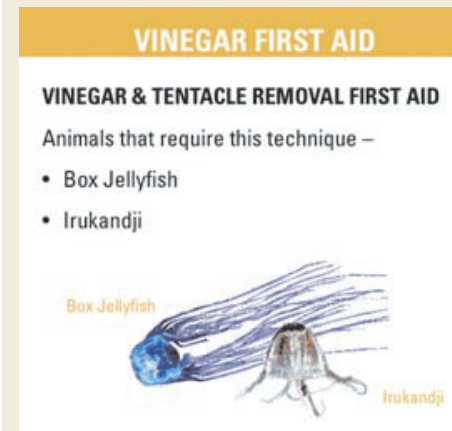

PROCEDURE

1 Pour plenty of vinegar over the wound (for at least 30 seconds).

2 Remove any tentacle material still stuck to the patient's skin.

3 Seek medical help as soon as possible.

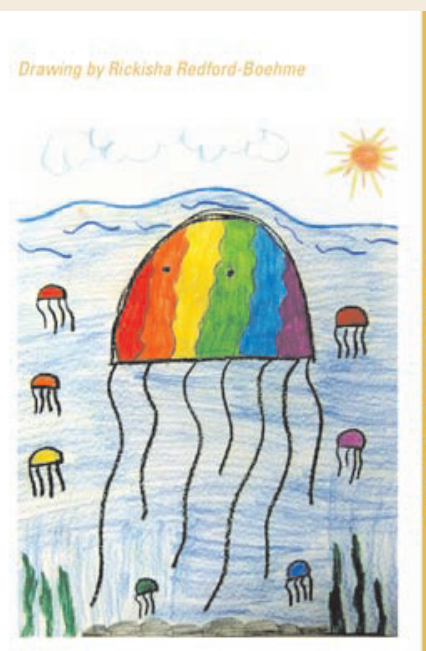

15

* Student Rickisha Redford-Bohme uses rainbow colours to represent the venom of the jellyfish. 
4 Context-based educational approaches help to transmit local knowledge and culture to young people

When [students] come into Western society they learn things like writing and reading, working things like a laptop. And there is an information outcome, like PowerPoint. But at home it's about talking to people, and you have to bring your grandmother and grandfather: ask them to tell stories.

Alistair James, traditional owner, Ndjebbana Clan Group (interview 31 May 2013).

We don't have pen and papers but we have what the men do on the walls [pointing to bark paintings], the traditional art and the stories, and the colours from the traditional art: from outside to inside, getting deeper. Sometimes the colour of the moiety, yellow, or red. The colours tell the country people came from, and those colours stay the same all the time. And their skin colours. In schools there are all sorts of colours but they should learn our two most important colours, which are Yirritja and Dhuwa.

Joseph Diddo, traditional owner Ndjebbana Clan Group (interview 31 May 2013).

and food sources (Box 5). For example, habitat damage

from the buffalo and wild pig threatens the water chestnut's availability to magpie geese and people. Traditional land management and science both have roles to play in redressing these imbalances.

The possibilities for this project are not isolated to the Maningrida community. Education in Australia is undergoing change: the new national curriculum places emphasis on Indigenous history and culture, suggesting potential for resources developed by Indigenous students to find a place beyond the Maningrida classroom. ${ }^{12}$ The students' spider discoveries have already contributed to Western science's understanding of biodiversity in Australia, and the possibility of future developments in Australian toxinology, and public health relating to injury prevention and treatment are enhanced by the strength of such interdisciplinary and cross-cultural partnerships. Further, the possibilities for enhanced biodiversity through traditional land management practices has Australia-wide relevance for tertiary science and health programs as well as resonance with the broader health and societal value of closer engagement with nature and place.

5 Students identify the seeds of the "necklace plant", an invasive European weed

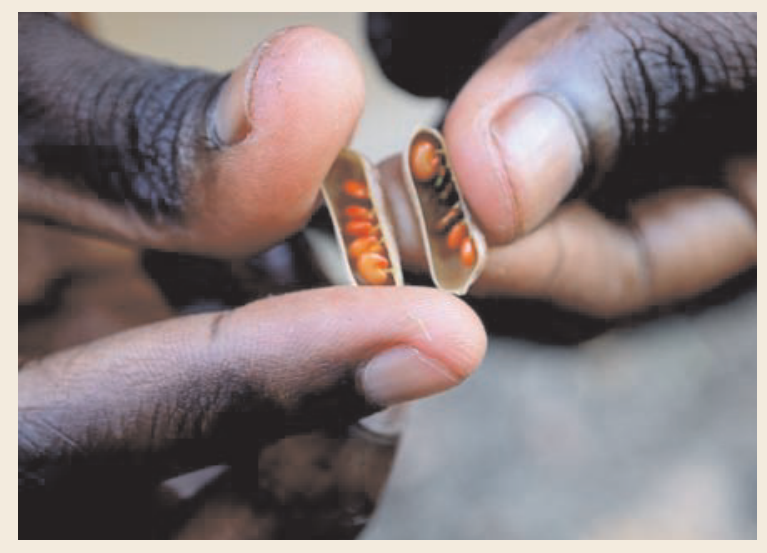

In turn, this project has become part of the University of Melbourne's reconciliation agenda. Supported by the Melbourne Social Equity Institute, we are conducting research into the partnership formation between the Maningrida community and the SPLT team, particularly where this partnership seeks to promote and raise Indigenous students' aspirations for engagement in further education.

Building this relationship with trust between stakeholders has taken time. Through it, the SPLT team have experienced "both ways" learning, showing that engaging communities to build capacity in health and education does not require closing in on diversity and heterogeneity, but rather, can move towards ways of being and knowing that embrace complexity and difference. This is potentially what could be lost in the mainstreaming of solutions to Indigenous disadvantage in both health and education. According to the elders and Djelk Rangers at Maningrida, being out on country is not just about the old ways, "it is the birthplace of the new ways for us". 1

Acknowledgements: Indigenous knowledge is reprinted here with permission from traditional owners Alistair James and Joseph Diddo, and teacher Heleana WauchopeGulwa of the Maningrida Community. We acknowledge Mason Scholes and Clinton Wearing of Maningrida College for facilitating the SPLT project activities and Roger Lowe, Phil Taylor and Keith Pigdon for their contributions to the development of the project. The SPLT project is supported by the Sutherland Trust, the Melbourne Graduate School of Education and National Health and Medical Research Council grant to the AVRU and the Melbourne Social Equity Institute. Emma Kowal reviewed this manuscript.

Competing interests: No relevant disclosures.

1 Altman JC, Kerins SP, editors. People on country: vital landscapes, Indigenous futures. Sydney: Federation Press, 2012.

2 Maningrida College. Bush tucker. Melbourne: Australian Venom Research Unit, 2011.

3 Burgess CP, Johnston FH, Berry HF, et al. Healthy country, healthy people: the relationship between Indigenous health status and "caring for country". Med J Aust 2009; 190: 567-572.

4 Anderson I, Baum F, Bentley M, editors. Beyond bandaids: exploring the underlying social determinants of Aboriginal health: papers from the Social Determinants of Aboriginal Health Workshop, Adelaide, July 2004. Darwin: Cooperative Research Centre for Aboriginal Health, 2007.

5 Fogarty W, Schwab RG. Indigenous education: experiential learning and learning through country. Canberra: Centre for Aboriginal Economic Policy Research, 2012. (CAEPR Working Paper No. 80/2012.) http://caepr.anu.edu. au/sites/default/files/Publications/WP/WP\%2080\%20Fogarty\% 20Schwab.pdf (accessed Apr 2013).

6 Maningrida Community Education Centre. 2011 operational plan. http:// www.det.nt.gov.au/_data/assets/pdf_file/0007/18844/Maningrida AOP2011.pdf (accessed Nov 2011).

7 Department of Families, Housing, Community Services and Indigenous Affairs. Closing the gap - Prime Minister's report 2013. Canberra: FaHCSIA, 2012. http:/ /www.fahcsia.gov.au/our-responsibilities/indigenous-australians/ publications-articles/closing-the-gap (accessed Jun 2013).

8 Kowal E. The politics of the gap: Indigenous Australians, liberal multiculturalism, and the end of the self-determination era. Am Anthropol 2008; 110: 338-348.

9 Christie M, Verran H, editors. Teaching from country. Learn Communities 2010; 2: 1-160. http://www.cdu.edu.au/centres/spill//publications_ijlsc.html?q= centres/spil/publications_ijlsc.html (accessed Jun 2013).

$10 \mathrm{Ma}$ Rhea Z. Partnership for improving outcomes in Indigenous education: relationship or business? J Educ Policy 2012; 27: 45-66.

11 Gorman JT, Williams R, Russell-Smith J, et al. A case for Indigenous fire management. In: Luckert MK, Campbell BM, Gorman JT, Garnett ST, editors. Investing in Indigenous natural resource management. Darwin: Charles Darwin University Press, 2007: 22-30.

12 Australian Curriculum, Assessment and Reporting Authority. Cross-curriculum priorities. Sydney: ACARA, 2011. http://www.acara.edu.au/curriculum/cross curriculum_priorities.html (accessed Apr 2013). 